I. Ushakova

Simon Kuznets Kharkiv National University of Economics, Kharkiv

\title{
APPLICATION OF COMPUTER AGENT MODELING FOR OPTIMIZATION OF THE ASSEMBLY PROCESS
}

\begin{abstract}
Computer modeling is a method for solving the problems of analysis or synthesis of a complex system based on the use of its computer model. Simulation, as a component of computer modeling, allows you to construct most of the possible states of the analyzed system. In this way it allows to correct the processes of assembling machines in a minimum time and with minimal costs, to foresee possible risks and to avoid unreasonable decisions regarding the organization of processes, to reduce material costs. Simulation gives the best results for modeling uncertain or probabilistic systems. Simulation, as a component of computer modeling, gives the best results for modeling systems with uncertainty or with a probabilistic nature. Mathematically calculating all possible variants of the system's behavior is a laborious task, and using average values in the calculations gives inaccurate results. For assembly production systems, simulation modeling is used to select the optimal production organization parameters. The aim of this work is to build a computer simulation model that allows you to evaluate the impact of production factors (number of employees, operating parameters and type of assembly process) on the assembly process and substantiate the effectiveness of the model. The current assembly process of the machine was considered for modeling. The assembly process includes: two streams of verification, synchronization of request from these two streams, and a machine collection stream. The vacated line starts servicing the application that entered the system earlier than others. Such a discipline is called "earlier entered - earlier served" (FIFO - First In - First Out).s from flows, and a machine assembly flow. An optimization experiment was carried out after the construction and verification of the simulation model. The maximum value of profit was chosen as the objective function. Iterations were performed during an optimization experiment. The optimal number of employees was selected for two inspection flows and a machine assembly stream in the assembly shop. The first experimental result showed the effectiveness of the request flow synchronization method. The following optimization experiment showed the relationship between the number of workers in certain threads of the assembly process and profit. The results of using agent-based models for simulation can be used to optimize assembly processes.
\end{abstract}

Keywords: computer model, simulation, agent model, assembly process, optimization.

\section{Introduction}

Nowadays, information technologies occupy a leading position in all fields, and automation and modeling are present everywhere. Increasingly, simulation is being used to create models to optimize processes, including the production of a particular product. The key processes of any enterprise are the fulfillment of certain requirements of the client in the production of products. Simulation allows you to test ideas or combinations of ideas, to find the optimal parameter values for different situations. All this can be done at no extra cost, without interfering with the production. These processes are strategically important and at the same time specific and unique. Customer order fulfillment processes include: order processing and execution; product development and design; product design; elimination of lack of production; production and installation, etc.

Computer modeling is a method of solving the problems of analysis or synthesis of a complex system based on the use of its computer model. Simulation is computer simulation and gives the best results if the system is uncertain or probabilistic [4]. This is due to the fact that mathematically calculating all possible variants of system behavior is a very time-consuming task, and the use of averages in the calculations is extremely inaccurate $[7 ; 15-16 ; 18]$. Simulation allows you to implement discrete-event and agent models, system dynamics models. This allows you to consider the whole variety of production situations in various areas.

Investigation of various systems and processes by simulation method is to determine the events that occur in the system. To facilitate this definition, it is advisable to first graphically depict the process of functioning of the system and highlight the characteristic events in it. The behavior of the simulated system is not independent; it is determined by events that depend on certain requirements. The process of imitation should reflect the timeline of events in the sequence that takes place in the real process.

Modeling is considered to be a recognized means of knowing reality. This process consists of two steps: developing a model and analyzing that model. Modeling makes it possible to explore the essence of complex processes and phenomena through experiments with its model instead of a real system. It is known that in order to make the right decision on the organization of the system does not necessarily need to know all the characteristics of the system. It is enough to analyze its simplified, approximate representation. 
Future system bottlenecks may investigate and evaluate the performance, cost, bandwidth optimization through modeling [9]. That is, all the main characteristics of the system can be explored before its creation. The best operating plans and timetables for existing complex systems will be developed based on simulation results. In organizational systems, simulation is becoming a major tool for comparing different management decisions and finding more effective ones. To describe real-world objects that function under random factors in practice, a class of mathematical models called queuing systems (QS) is often used. The functioning of these systems is in the nature of servicing incoming request. It is assumed that service requests form a stream - a sequence of applications with a special alternation of the moments of their appearance in time. The general concept of stream is based on the assumption that the event of interest to us will occur at previously unknown times $t_{1}, t_{2}, \ldots t_{k}$ (they are usually considered random).

Mathematical modeling of queuing systems consists of modeling the flow of applications and modeling the process of functioning of the aggregate of serving channels. To describe the QS, you must specify:

1) the incoming stream of requests that are received for service;

2) the procedure for placing an order in the queue and choosing from it;

3) the rule by which the service is carried out.

For assembly production, the purpose of simulation is to select the optimal parameters for the organization of production. Traditionally, for modeling such processes, discrete event models are used $[2 ; 6 ; 10-12$; 14]. Recently, however, some works have used an agent-based approach to simulate the assembly process. An Adaptive Large Neighborhood Search (ALNS) heuristic with next developed and integrated into the simulation model in [5]. In [17], an assembly process with a single stream is considered. At the same time, most assembly processes have multiple threads and queues.

This paper aims are to build a computer simulation model that allows to assess the impact of production factors (number of worker, operating parameters and type of assembly process) on the implementation of the assembly process and justify the effectiveness of the assembly process model.

\section{Statement of the main material}

Problem statement of simulation assembly machines. The current technological process of assembly of the machine unit was considered for simulation. To build the model it is necessary to develop and determine:

a scheme of the manufacturing process of the machine tool assembly in the assembly department,

a set of rules for receipt of applications in different situations, the number of channels and storages,

the storage capacity.

The assembly process of machines unit takes place in the assembling department, where all the necessary components for the assembly of the machine unit come (Fig. 1).

The assembly diagram includes three streams. In the first two streams, parts and blanks are tested before being sent to the assembly. The third stream is performed unit assembly. Each stream is characterized by:

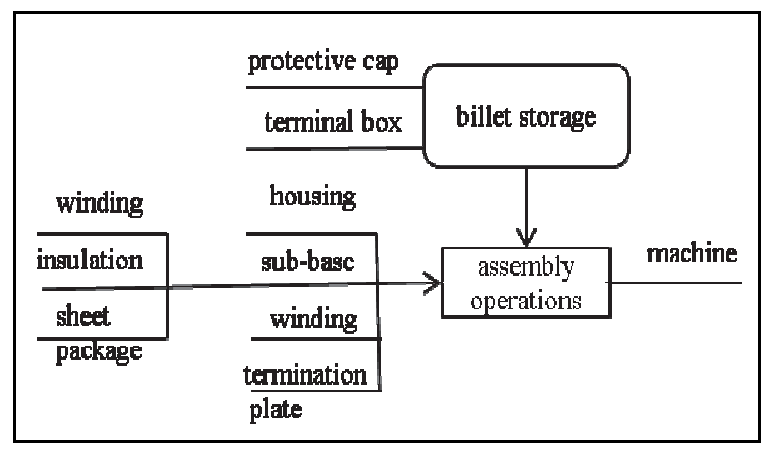

Fig. 1. Assembly process of the machine unit for welding semiautomatic devices

number of workers;

time to complete operations.

The input variables for the model are:

the number of employees at two inspection sites;

time to check details for defects;

the number of workers involved in the manufac-

ture of machine parts;

time for production;

data for the calculation of wages.

System Simulation AnyLogic. AnyLogic is a professional next-generation tool designed to develop and research simulation models. The AnyLogic toolkit is based on an object-oriented concept. Another basic concept is to represent the model as a set of interacting, parallel-functioning activities. An active object in AnyLogic is an object with its own functioning, interacting with the environment. It can include any number of instances of other active objects $[1 ; 3]$.

To create an AnyLogic model, you must create classes of active objects (or use AnyLogic library objects) and specify their relationships. AnyLogic interprets graphically created classes of active objects into Java classes, so you can take full advantage of objectoriented modeling. Active objects have clearly defined interfaces. They only interact with their environment through their interface elements. This facilitates the creation of systems with complex structures and also makes active objects reused.

OptQuest is built into AnyLogic, one of the best optimizers available today. The OptQuest Optimizer automatically finds the best values of the model parameters, given the set constraints. AnyLogic provides a user-friendly graphical interface for configuring and 
tracking optimization progress. Optimization consists of several sequential runs of a model with different parameter values.

The graphical modeling environment supports the design, development, documentation of the model, the execution of computer experiments, and optimization of parameters for a certain criterion [7]. AnyLogic used the concepts and tools of several classic areas of simulation modeling, such as: discrete-event modeling, system dynamics, and agent modeling for designing the model. Similarly, AnyLogic has the ability to integrate different approaches to get a better picture of how complex processes interact. In AnyLogic, agent modeling is combined with a discrete-event approach or system dynamics.

In this work, an agent method of simulation was used. Agent simulation is one of the modern methods of simulation modeling, a method that enables analyzing the work of decentralized agents and as such behavior determines the behavior of the whole system.

When applying agent methodology, the entities (objects) are considered as agents. Agents are some atomic entities that have activity, autonomous behavior, and decision-making ability, interaction with the environment and with other agents. The main purpose of agent models is to model the general behavior of a system based on assumptions about the individual nature of the behavior of active objects and the interaction of these objects in the system. In this simulation, the parameters of the active objects, that is, the agents themselves, are first set and their behavior is determined [8; 13]. In agent modeling, the overall algorithm of system behavior, unknown, is a consequence of the interaction of agents with each other and with the agent environment.

When creating the model, AnyLogic developed three phases of simulation: development of simulation models, their subsequent run for analysis, optimization. Model development is done in AnyLogic graphical editor, this software product contains numerous support tools that greatly simplify the work [7].

Creation of a simulation model. Simulation of queuing systems consists mainly of simulation of request flows and modeling of a set of channels served. For this purpose it is necessary to set the characteristics of the application streams and the application service flows on separate channels.

The purpose of modeling was chosen to study the parameters of the system, namely the evaluation of system characteristics in terms of its efficiency, that is, the appearance of downtime. To do this, you must determine the load of the primary and reserve channels, the number of interrupted messages processed by the primary channel and the reserve channel, as well as optimization parameters.
The process "Creating a simulation model" based on the agent approach (Fig. 2), includes such tasks as: creating the necessary model agents; adding the necessary variables; analysis of the current state of the model; error correction during the first run of the model; running the model and generating reports.

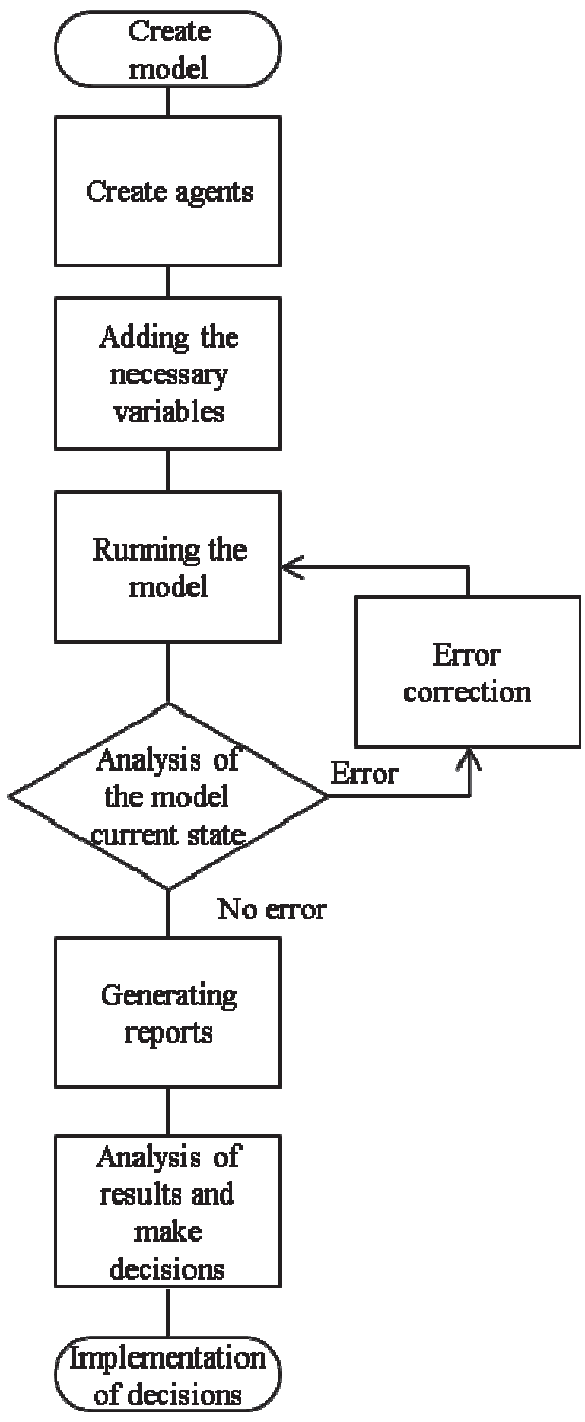

Fig. 2. Creating a simulation model

Agents can be any entity that matters to the system under study: people, households, cars, equipment, products, and companies. In our case, the components of the machine assembly processes will be used as agents. Model creation begins with the creation of new types of agents:

delay, delay1, delay2, delay3;

match;

queue, queue1, queue2;

sink;

source, source1;

and connectors:

Detal_1, Datal_2. 
Then the communication between the agents is set up, the environment is established and the simulation is started. Due to the individual actions of each agent, a global behavior is formed and modeled.

After creating the agents, model elements were created and the following parameters were added:

parameter $A$ is responsible for the number of workers in the first point of verification of parts;

parameter $B$ is responsible for the number of workers in the second check point;

parameter $C$ is responsible for the number of people involved in assembly the unit.

The value of the parameter for calculating the wages of workers for one shift was given by the dynamic variable $Z_{p}$ (Fig. 3). The wages of workers is determined as

$$
Z_{p}=(A+B+C) \times z
$$

Such parameters are used to calculate it:

$T_{1}-$ the time it takes to check one part in the first section;

$T_{2}$ - the time it takes to check one part in the second section;

$T_{3}$ - the time required to assemble one unit.

The values of the "Pribol" (profit) and "Prodano" (number of machines) variables will be calculated dynamically as the program runs.

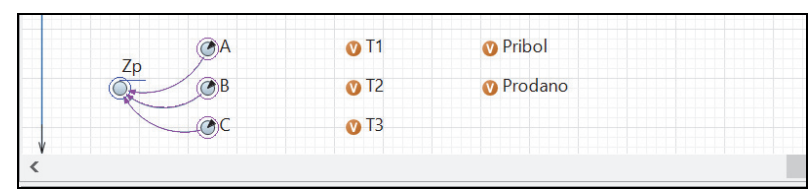

Fig. 3. Dynamic variable parameters

Fig. 4 presents a diagram of the process of assembling the machine unit. "Source" and "Source1" objects generate requests of a certain type. Requests are objects which are produced, processed, served or still somehow exposed to the actions of the simulated process. "queue" and "queue1" objects model a queue of pending details. "delay" and "delay1" objects delay requests for some time. This time is required to check the details. The "match" object synchronizes the two request streams by finding pairs of requests that match the specified parameters. Requests are accepted for service in the order of priority. The vacated line starts servicing the application that entered the system earlier than others. Such a discipline is called "earlier entered - earlier served" (in English literature FIFO - First In - First Out). Those requests for which the pair has not yet been found are stored in two queues.

Two java classes are created ("entity1" and "entity2"). These classes will include verified parts from first and second streams. Synchronization is performed under the condition:

$$
\text { entity } 1 . i d==\text { entity } 2 . i d
$$

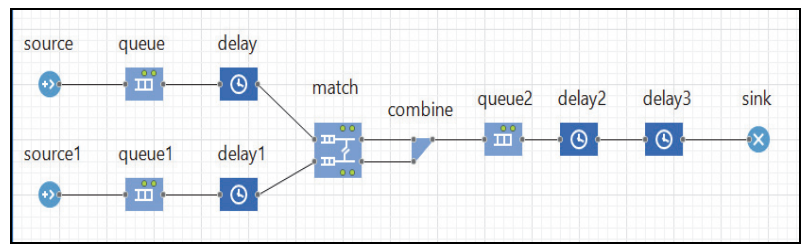

Fig. 4. Process diagram

The "Combine" object waits for two requests "detal_1" and "datal_2" to be received in ports, and then creates a new request "entity" and sends it to the output port. The application that arrives first is stored inside the facility until another application is received. As soon as another application arrives, the previous application immediately leaves the object.

The "queue2" object models a queue of parts before assembling aggregates. The object "delay2" is responsible for the calculation of the verified parts required for the assembly of the machine, and "delay3" for the calculation of the assembled finished machines

$$
\operatorname{Prodano}=\operatorname{Pr} \text { odano }+1 .
$$

To build a simulation model, the assemblage department was investigated for one day. The simulation workflow is shown in Fig. 5 and Fig. 6 parameters of the obtained model.

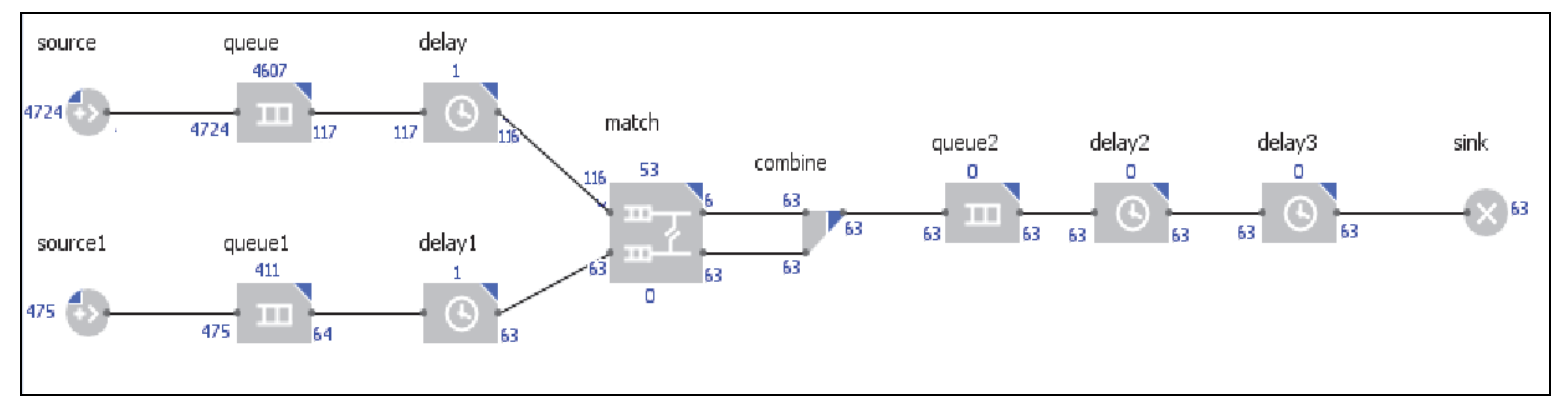

Fig. 5. Workflow of simulation modeling 


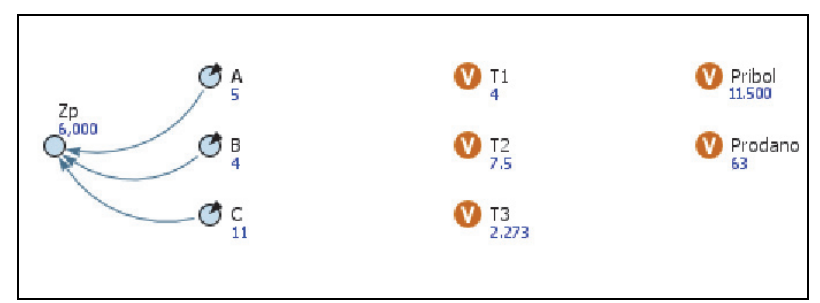

Fig. 6. The parameters obtained during the operation of the model

The analysis of the resulting model showed that 4724 parts were received on the first input and 475 on the second input. 63 units were collected and profit was $11.500 \$$. The time for checking parts on the first thread is 4 , on the second thread -7.5 , on the third thread 2.273. The experiment showed the required number of workers on the first stream -5 , on the second stream 4 , on the third stream -11 .

Process optimization. In addition, an optimization experiment was created. During this experiment, the values of the parameters were determined to achieve the optimal value of this objective function - the minimum wage of workers. As the objective function we choose profit. Profit is defined as the difference between the cost of assembled machine units and the wade of workers.

An optimization experiment requires an objective function to be specified. Since it is located in the root active class of the model, it is accessed by the root pointer. It is necessary to specify the purpose of optimization: search for minimum or maximum.

To start, you must specify an optimization stop mode. Most models use auto-stop mode. Next, you should specify the parameters that will change during the optimization process (Tabl. 1). For our study, these are the parameters A, B, C. The type of these parameters must be specified as continuous, the minimum value is 1 , the maximum value is 20 , and the default step is 1 .

After setting all the parameters, you need to define the experiment interface. For performance optimization need to run an experiment on performance.

Table 1

Parameter value

\begin{tabular}{|c|c|c|c|c|}
\hline \multirow{2}{*}{ Parameter } & \multirow{2}{*}{ Type } & \multicolumn{3}{|c|}{ Value } \\
\cline { 3 - 5 } & & Min & Max & Step \\
\hline A & Continuous & 1 & 20 & 1 \\
\hline B & Continuous & 1 & 20 & 1 \\
\hline C & Continuous & 1 & 20 & 1 \\
\hline
\end{tabular}

Upon completion of the experiment, the optimal value of the functional and the optimal value of the number of employees $A, B, C$ will be shown in the column "Better" (Fig. 7). On the right, the optimization process will be displayed as a graph (Fig. 8).

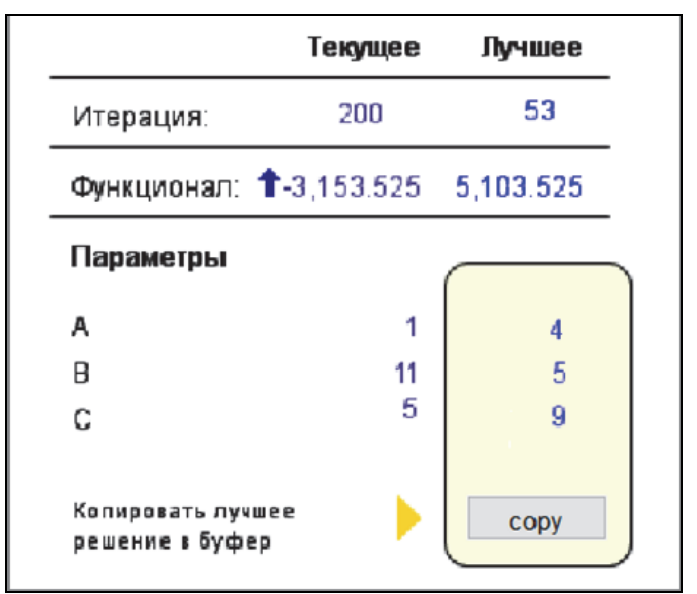

Fig. 7. Optimization experiment result (parameters)

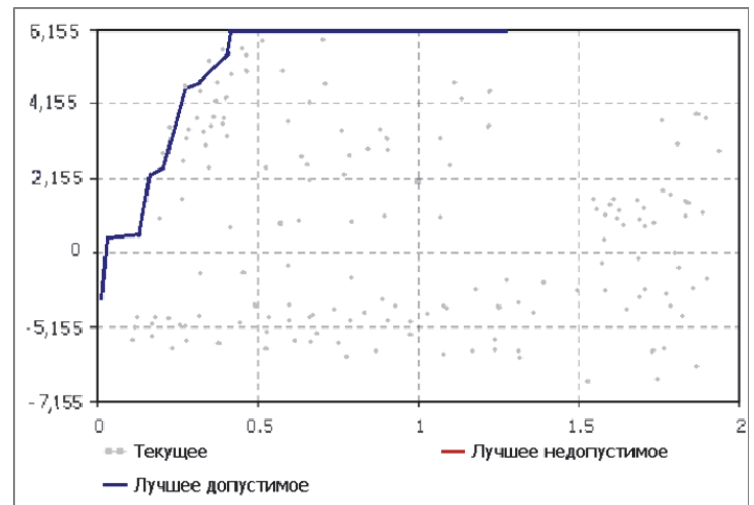

Fig. 8. Optimization experiment result (graph)

During the experiment, 200 iterations were performed, 53 iterations were the most profitable. The optimal number of workers to inspect and assemble the machine was selected as follows: $A-4 ; B-5 ; C-9$. These values are optimal for the number of employees in the assembly department.

\section{Conclusions}

The paper presents the developed agent model of the assembly process of machine. Simulation allows you to select the optimal parameters for the organization of assembly production with minimal cost. The agent approach is proposed to be used to simulate the assembly process. You can build an agent model using AnyLogic software product tools. Optimization of AnyLogic model consists in sequential execution of several runs of the model with different parameter values and finding of optimal for this task parameter values. Combining heuristics, neural networks and mathematical optimization, OptQuest allows you to find model parameter values corresponding to the maximum or minimum of the objective function, both under uncertainty and under constraints.

Taking into account the data on resources, a method of simulation modeling of machine assembly processes was used, which allows not only to analyze the characteristics of the model, but also to carry out 
structural, algorithmic and parametric synthesis of the model. As the objective function we choose profit. During the experiment iterations were performed, and optimal number of workers to inspect and assemble the machine unit was selected for the assembly department.
The first experimental result showed effectiveness method of synchronizing of the flow request. Next optimization experimental result showed the relationship between the number of workers in certain stream of the assembly process and profit.

\section{References}

1. Abar, S., Theodoropoulos, G., Lemarinier, P. and O'Hare, G. (2017), Agent Based Modelling and Simulation tools: A review of the state-of-art software, Computer Science Review, Vol. 24, pp. 13-33.

2. Anufriev, D.P., Holodov, A.Yu. and Volkov, A.A. (2015), "Modelirovanie setey massovogo obsluzhivaniya s posledovatelno soedinennyimi uzlami" [Modeling Queuing Networks with Serially Connected Nodes], Vestnik MGSU. Informatsionnyie sistemyi i logistika $v$ stroitelstve, No. 10, pp. 171-181.

3. Borshchev, A. (2013), The Big Book of Simulation Modeling: Multimethod Modeling with AnyLogic 6, AnyLogic North America, 614 p.

4. Borshhev, A., Mahdavi, A. and Zherebczov, A. (2019), "Imitaczionny`e modeli kak virtualnaya sreda dlya obucheniya i testirovaniya iskusstvennogo intellekta dlya biznes-prilozhenij" [Simulation models as a virtual environment for training and testing artificial intelligence for business applications], IMMOD-2019, available at: https://www.anylogic.ru /resources/articles/imitatsionnye-modeli-kak-virtualnaya-sreda-dlya-obucheniya-i-testirovaniya-iskusstvennogo-intellekta.

5. Danga, Q.V. and Phama, K. (2016), Design of a Footwear Assembly Line Using Simulation-based ALNS, Procedia CIRP, Vol. 40, pp. 596-601.

6. Filipchik, I.Yu. (2015), "Primenenie metoda diskretno-sobytijnogo modelirovaniya dlya povysheniya effektivnosti logisticheskoj sistemy sborochnogo uchastka" [Application of the discrete event modeling method to increase the efficiency of the logistics system of the assembly site], Electrical and computer systems, No. 18, pp. 65-69.

7. Han, S.H., Al-Hussein, M., Al-Jibouri, S. and Yu, H. (2012), Automated post-simulation visualization of modular building production assembly line, Automation in construction, Vol. 21, pp. 229-236.

8. Macal, C.M. (2016), Everything You Need to Know About Agent-based Modeling and Simulation, Journal of Simulation, Vol. 10, No. 2, pp. 144-156.

9. Mustafa, K. and Cheng, K. (2017), Improving production changeovers and the optimization: A simulation based virtual process approach and its application perspectives, Procedia Manufacturing, Vol. 11, pp. 2042-2050.

10. Naig, M., Chen, F.F. and Wan, H.D. (2017), Throughput rate improvement in a multiproduct assembly line using lean and simulation modeling and analysis, Procedia Manufacturing, Vol. 11, pp. 593-601.

11. Revina, I.V. and Vitt, P.A. (2019), "Imitaczionnoe modelirovanie sborochnogo proczessa" [Assembly process simulation], Dynamics of Systems, Mechanisms and Machines, Vol. 7, No. 3, pp. 86-94.

12. Sime, H., Jana, P. and Panghal, D. (2019), Feasibility of using simulation technique for line balancing in apparel industry, Procedia Manufacturing, Vol. 30, pp. 300-307.

13. Sudoa, Y. and Matsudaa, M. (2013), Agent based manufacturing simulation for efficient assembly operations, Forty Sixth CIRP Conference on Manufacturing Systems 2013. Proc. CIRP 7, pp. 437-442.

14. Timokhin, V.N. and Podskrebko, A.S. (2013), "Diskretno-sobytijnoe modelirovanie konvejernoj linii” [Discrete event simulation of the conveyor line], Business Informatics, No. 9, pp. 78-84.

15. Ushakova, I. (2016), Simulation of the impact social media on promoting education services, Proc. of 12th International Conference on ICTERI'16, CEUR-WS.org, June 21-24, Kyiv, Ukraine, available at: http://ceur-ws.org/Vol1614/paper_60.pdf.

16. Ushakova, I.A. and Dorokhov, A.V. (2013), "Kompyuternoe modelirovanie vliyaniya soczialnykh internet setej na formirovanie predpochtenij potrebitelej" [Computer modeling of the influence of social Internet networks on the formation of consumer preferences], MEDIJSKI DIJALOZI, Godina VI, Broj 15, pp. 61-71.

17. Ushakova, I.O. and Panasenko, S.O. (2012), "Modelyuvannya informaczijnogo vplivu soczialnikh merezh na loyalnist kliyentiv zasobami paketu Anylogic" [Modeling the impact of social networking on customer loyalty with Anylogic], Information Processing Systems, No. 4(102), pp. 76-80.

18. Zahraee, S.M., Rohani, J.M. and Wong, K.Y. (2018), Application of computer simulation experiment and response surface methodology for productivity improvement in a continuous production line: Case study, Journal of King Saud University. Engineering Sciences, Vol. 30, pp. 207-217.

\section{Список літератури}

1. Agent Based Modelling and Simulation tools: A review of the state-of-art software / S. Abar, G. Theodoropoulos, P. Lemarinier, G. O’Hare // Computer Science Review. - 2017. - Vol. 24. - P. 13-33.

2. Ануфриев Д.П. Моделирование сетей массового обслуживания с последовательно соединенными узлами / Д.П. Ануфриев, А.Ю. Холодов, А.А. Волков // Вестник МГСУ. Информационные системы и логистика в строительстве. 2015. - № 10. - С. 171-181.

3. Borshchev A. The Big Book of Simulation Modeling: Multimethod Modeling with AnyLogic 6. AnyLogic North America / A. Borshchev. $-2013 .-614$ p. 
4. Борщев А. Имитационные модели как виртуальная среда для обучения и тестирования искусственного интеллекта для бизнес-приложений [Электронный ресурс] / А. Борщев, А. Mahdavi, А. Жеребцов // ИМMOД-2019. - URL: https://www.anylogic.ru /resources/articles/imitatsionnye-modeli-kak-virtualnaya-sreda-dlya-obucheniya-i-testirovaniyaiskusstvennogo-intellekta.

5. Danga Q.V. Design of a Footwear Assembly Line Using Simulation-based ALNS / Q.V. Danga, K. Phama // Procedia CIRP. - 2016. - Vol. 40. - P. 596-601.

6. Филипчик И.Ю. Применение метода дискретно-событийного моделирования для повышения эффективности логистической системы сборочного участка / И.Ю. Филипчик // Электротехнические и компьютерные системы. - 2015. № 18. - С. 65-69.

7. Automated post-simulation visualization of modular building production assembly line / S.H. Han, M. Al-Hussein, S. Al-Jibouri, H. Yu // Automation in construction. - 2012. - Vol. 21. - P. 229-236.

8. Macal C.M. Everything You Need to Know About Agent-based Modeling and Simulation / C.M. Macal // Journal of Simulation. - 2016. - Vol. 10. - No. 2. - P. 144-156.

9. Mustafa K. Improving production changeovers and the optimization: A simulation based virtual process approach and its application perspectives / K. Mustafa, K. Cheng // Procedia Manufacturing. - 2017. - Vol. 11. - P. 2042-2050.

10. Naig M. Throughput rate improvement in a multiproduct assembly line using lean and simulation modeling and analysis / M. Naig, F.F. Chen, H.D. Wan // Procedia Manufacturing. - 2017. - Vol. 11. - P. 593-601.

11. Ревина И.В. Имитационное моделирование сборочного процесса / И.В. Ревина, П.А. Витт // Динамика систем, механизмов и машин. - 2019. - Том 7. - № 3. - С. 86-94.

12. Sime H. Feasibility of using simulation technique for line balancing in apparel industry / H. Sime, P. Jana, D. Panghal // Procedia Manufacturing. - 2019. - Vol. 30. - P. 300-307.

13. Sudoa Y. Agent based manufacturing simulation for efficient assembly operations / Y. Sudoa, M. Matsudaa // Forty Sixth CIRP Conference on Manufacturing Systems 2013. Proc. CIRP 7. - 2013. - P. 437-442.

14. Тимохин В.Н. Дискретно-событийное моделирование конвейерной линии / В.Н. Тимохин, А.С. Подскребко // Бизнес информатика. - 2013. - № 9. - С. 78-84.

15. Ushakova I. Simulation of the impact social media on promoting education services / I. Ushakova // Proc. of 12 th International Conference on ICTERI'16. CEUR-WS.org. - Kyiv, Ukraine, June 21-24, 2016. URL: http://ceur-ws.org/Vol1614/paper_60.pdf.

16. Ушакова И.А. Компьютерное моделирование влияния социальных интернет сетей на формирование предпочтений потребителей / И.А. Ушакова, А.В. Дорохов // MEDIJSKI DIJALOZI. -2013. - Godina VI. - Broj 15. - P. 61-71.

17. Ушакова I.О. Моделювання інформаційного впливу соціальних мереж на лояльність клієнтів засобами пакету Anylogic / I.О. Ушакова, С.О. Панасенко // Системи обробки інформації. - 2012. - № 4(102). - С. 76-80.

18. Zahraee S.M. Application of computer simulation experiment and response surface methodology for productivity improvement in a continuous production line: Case study / S.M. Zahraee, J.M. Rohani, K.Y. Wong // Journal of King Saud University. Engineering Sciences. - 2018. - Vol. 30. - P. 207-217.

Received by Editorial Board 10.01.2020 Signed for printing 11.02.2020

\section{Відомості про автора:}

\section{Ушакова Ірина Олексіївна}

кандидат економічних наук доцент

доцент кафедри

Харківського національного економічного

університету ім. С. Кузнеця,

Харків, Україна

https://orcid.org/0000-0001-8315-0917

\section{Information about the author:}

\section{Iryna Ushakova}

Candidate of Economic Sciences Associate Professor

Senior Lecturer

of Simon Kuznets Kharkiv National

University of Economic,

Kharkiv, Ukraine

https://orcid.org/0000-0001-8315-0917

\title{
ЗАСТОСУВАННЯ КОМП'ЮТЕРНОГО АГЕНТНОГО МОДЕЛЮВАННЯ ДЛЯ ОПТИМІЗАЦІЇ СКЛАДАЛЬНОГО ПРОЦЕСУ
}

\author{
І.О. Ушакова
}

Комп'ютерне моделювання - це метод вирімення задач аналізу або синтезу складної системи на основі використання ї̈ комп'ютерної моделі. Імітачійне моделювання, як складова комп'ютерного моделювання, дозволяє побудувати більшість можливих станів аналізованої системи. Тим самим воно дає можливість коригувати процеси складання верстатів за мінімальний час та з мінімальними витратами, передбачити можливі ризики і уникнути необтрунтованих рішень щодо організаиії процесів, зменшити матеріальні витрати. Імітаційне моделювання дає найкращі результати для моделювання систем з невизначеністю або з імовірнісним характером. Математично прорахувати всі можливі варіанти поведінки системи - трудомістке завдання, а використання в розрахунках середніх значень дає неточні результати. Для систем складального виробництва імітаційне моделювання використовується, щзоб вибрати оптимальні параметри організачії виробництва. Метою даної роботи є побудова комп'ютерної 
імітаційної моделі, яка дозволяе оцінити вплив виробничих факторів (кількість працюючих, робочі параметри та тип проиесу складання) на процес складання та обтрунтувати ефективність моделі. Для моделювання було розглянуто діючий технологічний процес складання верстата. Технологічний прочес складання включає: два потоки перевірки деталей, синхронізацію заявок з цих двох потоків і потік складання верстата. Після побудови і перевірки імітаційної моделі було проведено оптимізаційний експеримент. В якості иільової функиії було обрано максимальне значення прибутку. В ході оптимізаиійного експерименту були виконані ітерації. Для складального цеху було вибрано оптимальну кількість працівників для потоків перевірки і збирання верстату. Перший експериментальний результат показав ефективність методу синхронізаиії потоку запитів. Наступний оптимізаційний експеримент показав взаємозв'язок між кількістю робочих в певних потоках процесу збирання і прибутком. Результати застосування агентних моделей для імітаційного моделювання можуть використовуватися для оптимізації процесів складальних виробництв.

Ключові слова: комп 'ютерна модель, імітаційне моделювання, агентна модель, складальний процес, оптимізація.

\section{ПРИМЕНЕНИЕ КОМПЬЮТЕРНОГО АГЕНТНОГО МОДЕЛИРОВАНИЯ ДЛЯ ОПТИМИЗАЦИИ СБОРОЧНЫХ ПРОЦЕССОВ}

И.А. Ушакова

Компьютерное моделирование - это метод решения задач анализа или синтеза сложной системы на основе использования ее компьютерной модели. Имитационное моделирование, как составляющая компьютерного моделирования, позволяет построить большинство возможных состояний рассматриваемой системы. Тем самым оно дает возможность корректировать процессы сборки станков за минимальное время и с минимальными затратами, предусмотреть возможные риски и избежсать необоснованных решений по организации процессов, уменьшить материальные затраты. Имитационное моделирование дает лучшие результаты для моделирования систем с неопределенностью или с вероятностным характером. Математически просчитать все возможные варианты поведения системытрудоемкая задача, а использование в расчетах средних значений дает неточные результаты. Для систем сборочного производства имитационное моделирование используется, чтобы выбрать оптимальные параметры организации производства. Целью данной работь является построение компьютерной имитационной модели, которая позволяет оценить влияние производственных факторов (количество работающих, рабочие параметры и тип процесса сборки) на проиесс сборки и обосновать эффективность модели. Для моделирования был рассмотрен действующий технологический прочесс сборки станка. Технологический прочесс сборки включает: два потока проверки деталей, синхронизачию заявок из этих двух потоков и поток сбора станка. После построения и проверки имитационной модели был выполнен оптимизационный эксперимент. В качестве иелевой функции было выбрано максимальные значение прибыли. В ходе оптимизачионного эксперимента были выполнены итерации. Для сборочного чеха было выбрано оптимальное количество работников для двух потоков проверки и потока сбора станка. Первый экспериментальный результат показал эффективность метода синхронизации потока запросов. Следующчй оптимизачионный эксперимент показал взаимосвязь между количеством рабочих в определенных потоках прочесса сборки и прибылью. Результаты применения агентных моделей для имитационного моделирования могут использоваться для оптимизации процессов сборочных производств.

Ключевые слова: компьютерная модель, имитачионное моделирование, агентная модель, сборочный процесс, оптимизация. 